\title{
Does CEO Turnover Affect Stock Market Performance through Company Performance in
} Indonesian Companies?

\author{
Nera Marinda Machdar ${ }^{1}$
}

\section{'Institute Teknologi dan Bisnis Kalbis Faculty of Business, Department of Accounting, Jalan Pulomas Selatan Kav.22, Jakarta 13210, Indonesia. Email:nera.marinda@kalbis.acid}

Licensed:

This work is licensed under a Creative Commons Attribution 4.0 License.

Keywords:

CEO turnover

Stock market performance

Company performance

Abnormal return

Tobin's $Q$

JEL Classification

M5; L1; G3.

\begin{abstract}
This study analyzes whether CEO turnover affects stock market performance through company performance in Indonesian companies. Specifically, this study examines: (1) Does the CEO turnover affect the stock market performance? (2) Does the CEO turnover affect the company performance and (3) Does the CEO turnover affect the stock market performance through the company performance? This study does not test the CEO turnover due to death, forced resignation, voluntary departures, and age-related retirement considering that almost all companies in Indonesia are family companies. This study uses the manufacturing companies listed on the Indonesia Stock Exchange as an analysis unit with the study period during 2010-2015. The finding of this study concludes that (1) the CEO turnover has a positive effect on the stock market performance, (2) the CEO turnover has a positive effect on the company performance, and (3) the CEO turnover does not affect the stock market performance through the company performance. This study has an implication from a theoretical perspective, i.e. the CEO turnover has a positive effect on the stock market performance and the company performance. However, CEO turnover does not affect the stock market performance through company performance. Then, the company performance is not an intervening variable of the effect of the CEO turnover on the stock market performance.
\end{abstract}

Funding: This study received no specific financial support.

Competing Interests: The author declares that there are no competing interests regarding the publication of this paper.

\section{Introduction}

The Chief Executive Officer (CEO) holds the highest executive position in the company. CEO is responsible for the stability of the company. The CEO makes the most strategic decisions and responsible for the company's operations and the company's stability. The CEO affects directly on the allocation of the company's resources. Strategic decisions include entering new markets, launching new products, or rearranging company structures (Mutwiri, 2013).

Datta and Rajagopalan (1998) infer that characteristics such as tenure, age, education level, and functional background are components of a knowledge base for the chief executive officer. It means that a composition of CEO characteristics that can be observed and quantified such as education and work experience, and characteristics unobservable and unquantifiable e.g. leadership skills and team development (Bhagat, Bolton, \& Subramanian, 2010). Indonesia has a two-tier board system, namely: Board of Directors and Board of Commissioners (Setiawan, Phua, Chee, \& Trinugroho, 2017). In Indonesia, The CEO is the chairman of the Board of Directors.

CEO turnover is an important event in the life of the company (Clayton, Hartzell, \& Rosenberg, 2005). Many factors can influence CEO turnover decisions including accounting performance, stock performance, organizational factors, mergers and acquisitions, CEO personality, and audits.

Furthermore, some researchers revealed other factors that influence CEO turnover, namely CEO share ownership (Denis \& Denis, 1995) the composition of the board of directors, and equity compensation (Balsam \& Miharjo, 2007). CEO turnover is done by the board of directors before or after the term ends. Changes in CEOs that are made before the end of the term of office can be caused by death, or cannot reach the company's 
main objectives. With the CEO turnover, there is a possibility of changes in the company's management in terms of implementing new rules and procedures, as well as changes in policies that are set so that the company's main objectives are achieved.

In public companies, any changes to key people cause a correction in stock market investor perceptions of short-term and long-term corporate development opportunities (Gangloff, Connelly, \& Shook, 2014). In the short term, the possibility of companies experiencing sudden changes in company valuation, and in the long run causes limited access to obtain capital and reduce the company's capacity to generate profits. According to Byrka-Kita, Czerwiński, and Preś-Perepeczo (2017) investors revised the company's value expectations when the company released CEO turnover announcements through the stock exchange.

On the other hand, investors have access to additional information from various sources including analyst reports, prior announcements and the media. By utilizing the information contained in these sources, investors revise their beliefs about the reasons for actual CEO turnover (Zhang, Wierschem, Mediavilla, \& Hong, 2016).

The stock market in a country has an important role in building the economy of a country. It provides a way to raise funds, for securities trading including futures, options and other derivatives.

It also provide opportunities for investors to generate abnormal returns on stock investment. CEO turnover can affect stock market performance and company performance (Zhang et al., 2016). The company performance over a certain period of time is a reflection of the company's overall success. The achievement company performance is a key concept in the current economic, which is formed by rapid change, intense competition, and globalization (Machdar, 2017).

The difference in the results of stock market performance analysis with CEO turnover announcements is done by several factors about specific succession: (1) CEO change process: routine and non-routine (Denis \& Denis, 1995; Dherment-Ferere \& Renneboog, 2000; Kang \& Shivdasani, 1996; Neumann \& Voetmann, 1999; Warner, Watts, \& Wruck, 1988) and (2) the origin of incoming CEOs: insiders or outsiders (Friedman and Singh, 1989) (3) voluntary or forced (Adams \& Mansi, 2009; Dedman \& Lin, 2002; Denis \& Denis, 1995; Friedman \& Singh, 1989; Furtado \& Rozeff, 1987; Huson, Malatesta, \& Parrino, 2004). The findings from previous studies are not consistent because the analysis of the causes of CEO turnover are different.

This study analyzes whether CEO turnover affects stock market performance through company performance in Indonesian companies. Specifically, this study examines: (1) Does the CEO turnover affect the stock market performance? (2) Does the CEO turnover affect company performance, and (3) Does the CEO turnover affect the stock market performance through the company performance? This study does not examine the specific reason the CEO turnover like death, forced resignation, voluntary departures, and agerelated retirement considering that almost all companies in Indonesia are family companies. According to data from the International Finance Corporation (IFC) that almost 95\% of business owners in Indonesia is family owned (Anjungsari, 2016). Rachpradit, Tang, and Khang (2012) confirmed that the probability of CEO turnover is lower when the company is controlled by the family. In this case, the CEO is part of the controlling family. Then, CEO turnover does not relate to company performance.

The paper is organized as follows. Section 2 presents the theoretical background and hypotheses development. Section 3 describes the data and methodology. Section 4 provides the results and discussions. Section 5 proposes the conclusions.

\section{Theoretical Background and Hypotheses Development}

Some theories have been explained by previous researchers regarding the effect of CEO turnover on stock market performance and company performance, including the upper echelon theory, signaling theory, and scapegoat hypothesis theory. The upper echelon theory suggests that the CEO play a critical role in creating organizational outcomes (Zhang et al., 2016). Thus, the change of CEO is an important issue that has an important impact on companies' strategies, and in turn on stock market performance and company performance.

Signaling theory assumes that changes in key people in the company indicate investors have not fulfilled expectations because the company's performance is actually not satisfactory or that management currently does not meet challenges and must be replaced (Byrka-Kita et al., 2017).

Gamson and Scotch (1964) introduced the scapegoat hypothetical theory. This theory argues that the main purpose of CEO turnover is to reach the target of organizational frustration when performance decreases.

This theory uses the assumption that when the manager's condition does not substantially affect the performance of the company, then the replacement of managers calms the public who mistakenly believes in its strength in determining the company's performance (Dherment-Ferere \& Renneboog, 2000). In other words, the replacement of the $\mathrm{CEO}$ acts as a symbolic act that sends a positive signal to the outside world, even though it is actually not significant.

Furthermore, Pessarossi and Weill (2012) assert that this theory predicts no abnormal changes in stock returns around the CEO turnover announcement due to the market assumes the CEO is worth it. The next CEO is not expected to have higher capabilities (Pessarossi \& Weill, 2012). 
Some studies report significantly positive effect to stock market performance as proxied by abnormal return around a CEO turnover (Adams \& Mansi, 2009; Denis \& Denis, 1995; Furtado \& Rozeff, 1987; Huson et al., 2004; Kang \& Shivdasani, 1996; Reinganum, 1985; Salas, 2010; Weisbach, 1988). The result indicates that the CEO turnover announcement is useful information for investors in order to make investment decisions. Most of the findings are higher stock abnormal returns for routine CEO turnover compared to voluntary CEO turnover (Adams \& Mansi, 2009; Furtado \& Rozeff, 1987; Huson et al., 2004).

Furthermore, others a negative effect on abnormal return around a CEO turnover (Cheung \& Jackson, 2013; Dedman \& Lin, 2002; Warner et al., 1988). Warner et al. (1988) tested the association between market stock returns and subsequent top management changes. Consistent with internal monitoring of management, the study found an inverse relationship between the probability of a management change and a firm's share performance.

However, it considers only retrospective performance as an explanation for the turnover, and do not regard the post-turnover stock performance. Dedman and Lin (2002) investigated the effect of CEO turnover processes on market reaction in the UK. Their sample consists of 24 fired turnover process, 28 voluntarily signed off, 22 normal turnover processes, and 10 moved to another firm. The result implies that UK investors perceive CEO turnover as bad news. It shows a negative market reaction to non-routine or forced CEO turnover.

They detected negative abnormal returns significantly on average after forced CEO turnover. Cheung and Jackson (2013) stated that the replacement of forced CFO is in accordance with the signaling effect theory in conveying previously unknown information to the market. The findings of this study that forced CEO turnover produced more negative cumulative abnormal returns.

Researchers who observe stock market performance by focusing on CEO turnover characteristics delivered mixed results (Denis \& Denis, 1995; Dherment-Ferere \& Renneboog, 2000; Friedman \& Singh, 1989; Huson et al., 2004; Kang \& Shivdasani, 1996; Neumann \& Voetmann, 1999; Setiawan, 2008; Weisbach, 1988) investigated the relationship between the composition of the board of directors (board dominated by insiders and outsiders) and CEO turnover.

The findings that there is a positive relationship, but there is no difference in the impact between board decisions that are dominated by insiders and outsiders. Friedman and Singh (1989) analyzed CEO turnover by considering the nature of turnover (forced versus voluntary) and the origin of the successor (insider versus outsider). The findings confirm that the organizational context and content of organizational succession influence market reactions to CEO turnover announcements. Furthermore, the stock price reaction to the CEO turnover announcement is heterogeneous, that is, the market reacts positively to succession announcements when the company's previous performance is bad, and the market reaction is negative when the CEO dies or becomes disabled.

Denis and Denis (1995) examined the effect of routine and non-routine processes on CEO turnover. This study identified 69 non-routine and normal processes at CEO turnover. The results show that investors react positively to both processes: routine and non-routine CEOs with changes in $2.5 \%$ company performance and $0.63 \%$ abnormal returns. Another finding is that investors' reaction to non-routine turnover is greater than routine changes.

This confirms that CEO turnover is good news and contributes significantly to stock market performance and company performance. Kang and Shivdasani (1996) analyzed the investor reaction to CEO succession announcements in Japan, and the amount of sample is 432 CEO turnover announcements for the period 1985 to 1990 . The results show that the market reacts positively to CEO turnover. Japanese investor perceived that this news is good news, and a new CEO brings new insight into leading the company. Neumann and Voetmann (1999) investigated on market reaction to CEO turnover announcements in Denmark.

Their sample consists of 39 non-routine change and 42 voluntarily change for the period 1994-1998. The results of their research show that the market reacts positively to non-routine change, but negatively to routine changes. It means that Denmark investors prefer non-routine changes more than routine changes.

Dherment-Ferere and Renneboog (2000) analyzed stock price reactions to changes in top management by considering various types of CEO turnover: forced resignation, voluntary departure, and age-related pensions. The announcement of forced CEO resignation has a significant positive effect on stock prices. While voluntary resignation has no effect on stock prices, and CEO turnover due to age has a negative effect on stock prices. Huson et al. (2004) tested the market reaction to the announcement of CEO changes in the US during the period 1971 to 1995 using a sample of 1200 CEO turnover announcements.

The results showed that during the two days of observation ( $t-1$ and to) the market reacted positively (CAR 0.354\%) to the CEO turnover announcement. Furthermore, the company experienced a significant increase in company performance after forced and voluntary CEO turnover. Setiawan (2008) found that CEO turnover had a positive effect on the market reaction. CEO turnover has information content and is a signal for investors. The announcement of CEO turnover is good news, so the market reacts positively to this announcement. The market prefers routine processes and comes from within the company at CEO turnover. Investors believe that this smooth succession brings the company to unusual changes in company management. Furthermore, when a change in routine and a new CEO comes from outside, the market does not 
like it and reacts negatively. Other studies that examine the effect of CEO turnover on financial performance are still a little.

Dahya, McConnell, and Travlos (2002) found that there is a negative impact on CEO turnover on company performance. Moreover, Jenter and Lewellen (2014) found a close relationship between company performance and CEO turnover.

In addition, the result estimated that more than $40 \%$ of turnover in the first eight years is influenced by company performance. Jenter and Lewellen (2014) concluded that CEO turnover affects positively the company performance. Meanwhile, Ishak, Ismail, and Abdullah (2013) found that company performance after CEO turnover increased slightly and that the increase was significant two years after succession. In the case of forced CEO turnover, there is no increase in company performance. On the other hand, voluntary CEO turnover shows a decline in performance.

Few studies have been done in the Indonesian context, such as Lindrianasari and Hartono (2011) and Setiawan et al. (2017). Lindrianasari and Hartono (2011) found a negative relationship between firm performance and the probability of CEO turnover, while Setiawan et al. (2017) concluded that CEO turnovers in Indonesia do not affect the firm performance.

Based on the aforementioned explanation and various results from previous studies, the following hypotheses are proposed:

Hypothesis 1: The CEO turnover affects positively on the stock market performance.

Hypothesis 2: The CEO turnover affects positively on the company performance.

Hypothesis 3: The CEO turnover affects positively on stock market performance through company performance.

\section{Data and Methodology}

This study uses secondary data. The sample of this study comprised of 103 firms listed on the Indonesia Stock Exchange during the 2010-2015 period. In total, 618 firm-year observations are obtained for analysis. In processing data with regression logit models, there were missing cases from CEO turnover 349 firms or $56.5 \%$, so that the total firms analyzed were only 269 firms. This sample data is obtained from Indonesian Capital Market Directory (ICMD), IDX Website www.idx.co.id. Yahoo Website www.finance.yahoo.com and www.duniainvestasi.com. This study was processed using SPSS with logit regression models.

The dependent variable is the stock market performance, which is measured by abnormal return by dividing the individual return with the market return (Hartono, 2013). The independent variable is the CEO turnover. CEO turnover is coded as 1 if there is CEO turnover, o for continuing CEO from the previous year (Zhang et al., 2016). The intervening variable is Tobin's Q, calculated as the sum of the market value of equity and the book value of total assets minus the book value of equity, all divided by the book value of total assets (Ross, Westereld, \& Jafe, 2013). The model of this study as follows:

$$
\text { Model 1: ABNRET }=\delta_{0}+\delta_{2} \text { TOCEO }+\varepsilon_{1}
$$

In Model 1 the dependent variable is stock market performance (ABNRET), and the independent variable is turnover chief executive officer (TOCEO).

Model 2: PERFM $=\delta_{0}+\delta_{1}$ TOCEO $+\delta_{3}$ ABNRET $+\varepsilon_{2} \ldots \ldots \ldots \ldots \ldots$ (2)

In Model 2 the dependent variable is company performance (PERFM), and the independent variable is turnover chief executive officer (TOCEO) and stock market performance (ABNRET). In this study, company performance acts as the intervening variable.

\section{Result and Discussion turnover chief executive officer.}

\subsection{Descriptive Statistics}

Table 1 presents a summary of descriptive statistics for all the variables used in this study. From Table 1, the CEO turnover (TOCEO), abnormal return (ABNRET) and company performance (PERFM) have a standard deviation value greater than the average value. This indicates that all the variable of the sample does not have a considerable variation. In other words, the sample of firms provides a reasonable variance.

\begin{tabular}{|c|c|c|c|c|c|}
\hline Variable & $\mathbf{N}$ & Minimum & Maximum & Mean & Std. Deviation \\
\hline TOCEO & 618 & 0.0000 & 1.0000 & 0.1084 & 0.3112 \\
\hline PERFM & 618 & 0.2140 & 7.2989 & 1.1927 & 1.3109 \\
\hline ABNRET & 269 & 0.0041 & 15.1590 & 0.6979 & 1.5640 \\
\hline
\end{tabular}


Table-2. Number of Turnover CEO by Year.

\begin{tabular}{c|c|c|c}
\hline Year & Changed CEO & Unchanged CEO & Total Firms \\
\hline 2010 & 9 & 94 & 91 \\
\hline 2011 & 12 & 96 & 103 \\
\hline 2012 & 7 & 88 & 103 \\
\hline 2013 & 15 & 90 & 103 \\
\hline 2014 & 13 & 92 & 103 \\
\hline 2015 & 11 & 551 & 103 \\
\hline Number & 67 & $89.16 \%$ & 618 \\
\hline Percentage & $10.84 \%$ & & $100 \%$ \\
\hline
\end{tabular}

Table 2 provides the original number of turnover CEO by year. From the data presented in Table 2 , the CEO replacement is $10.84 \%$ during the 2011-2016 period. While the remaining $89.16 \%$ did not experience CEO turnover. This condition is likely to occur because companies in Indonesia are mostly family companies even though the company has sold their shares on the stock exchange. In processing data with regression logit models, there were missing cases from CEO turnover 349 firms or $56.5 \%$, so that the total firms analyzed were only 269 firms. Out of 269 firms that experienced CEO turnover only 29 firms and the remaining 240 did not experience firm turnover.

\subsection{Analysis of Research Results}

Table 3 presents the result of the t-statistical test. The Hosmer and Lemeshow Test results were 5,067 and significant at 0.750 . This indicates that the model is to be fit and acceptable because the significance value is above 0.05. In logistic regression, the coefficient of determination is obtained from the Nagelkerke R Square value, which is equal to 0.055 . This means that the variables of abnormal stock returns and company performance can be explained by CEO turnover variable of $5.5 \%$, while the remaining $94.5 \%$ is explained by variables outside the research model.

It can be seen in Table 3 that stock market performance (ABNRET) has a significance value of 0.022. It shows that CEO turnover has a positive effect on stock market performance. Therefore, hypothesis 1 is accepted. This result is in line with the finding of Salas (2010); Adams and Mansi (2009) and Huson et al. (2004). Moreover, company performance has a significance value of 0.074. It shows that CEO turnover has a positive effect on company performance. Thus, hypothesis 2 is accepted. This result is in line with the result of Ishak et al. (2013). CEO turnover positively affects stock market performance because CEO after succession usually bring new ideas and strategies into the company and take more drastic actions to achieve success. The CEO candidates should have an extraordinary track record that is superior to the CEO before succession.

Table-3. Results of Effect CEO Turnover on Stock Market Performance and Company Performance.

\begin{tabular}{|c|c|c|c|c|}
\hline Variable & Predicted Sign & Coefficient & Sig. & Prob. \\
\hline Constant & & -2.522 & 0.000 & \\
\hline ABNRET & + & 0.199 & 0.022 & ***) \\
\hline PERFM & + & 0.124 & 0.074 & *) \\
\hline Hosmer and Lemeshow Test & & 5.067 & 0.750 & \\
\hline Nagelkerke R Square & & & 0.055 & \\
\hline
\end{tabular}

Table 4 presents the result of the coefficient direct and indirect effect of the CEO turnover on the stock market performance through the company performance. The t-statistic is smaller than t-table, so it can be concluded that no mediating effect. It means that CEO turnover does not affect the stock market performance through company performance. Thus, hypothesis 3 is rejected. In other words, company performance is not an intervening variable. Investors have additional information from various sources including analyst reports, previous announcements, and media other than the company's financial statements. Therefore, investors can revise their beliefs about the reasons for the actual CEO turnover by utilizing the information contained in these sources (Zhang et al., 2016).

Table-4. Results of Effect CEO Turnover on Stock Market Performance through Company Performance.

\begin{tabular}{c|c|c|c|c|c|c}
\hline & $\begin{array}{c}\text { Coefficient } \\
\text { Direct } \\
\text { Effect }\end{array}$ & $\begin{array}{c}\text { Coefficient } \\
\text { Indirect } \\
\text { Effect }\end{array}$ & $\begin{array}{c}\text { Total } \\
\text { Effect }\end{array}$ & t-Stat & t-table & Result \\
\hline $\begin{array}{c}\text { TOCEO- PERFM } \\
\text {-ABNRET }\end{array}$ & 0.199 & -0.006 & 0.194 & -0.4529 & 1.9638 & $\begin{array}{c}\text { No mediating } \\
\text { effect }\end{array}$ \\
\hline
\end{tabular}




\section{Conclusion}

This study aims to analyze the effect of CEO turnover on stock market performance through company performance in Indonesia. The finding of this study can be concluded that (a) the CEO turnover has a positive effect on the stock market performance, (b) the CEO turnover has a positive effect on the company performance, and (c) the CEO turnover does not affect the stock market performance through the company performance. This study has an implication from a theoretical perspective, i.e. the CEO turnover has a positive effect on the stock market performance and the company performance. However, CEO turnover does not affect the stock market performance through company performance. Then, the company performance is not an intervening variable of the effect of the $\mathrm{CEO}$ turnover on the stock market performance.

This study has some limitations. First, the analysis of CEO turnover does not consider important characteristics such as the successor origin (insiders or outsiders), departure type (forced or voluntary), and age-related retirement, and combination thereof. Future research should distinguish CEO turnover from the criteria mentioned so that the results obtained reflect the impact of CEO turnover conditions. Second, abnormal stock returns do not calculate in the short term or 3-5 days after the replacement of the CEO. Future studies should observe abnormal stock returns by using event studies in the narrow window so that the results obtained appropriate completely.

\section{References}

Adams, J. C., \& Mansi, S. A. (2009). CEO turnover and bondholder wealth. Journal of Banking E Finance, 33(3), $522-533$.

Anjungsari, P. A. (2016). IFC and Indonesia's family business nusantara foundation help family-owned enterprises improve corporate governance. Jakarta: International Finance Corporation, World Bank Group.

Balsam, S., \& Miharjo, S. (2007). The effect of equity compensation on voluntary executive turnover. Journal of Accounting and Economics, 43(1), 95-119.

Bhagat, S., Bolton, B., \& Subramanian, A. (2010). CEO education, CEO turnover, and firm performance. Retrieved from https://ssrn.com/abstract=1670219.201 or http://dx.doi.org/10.2139/ssrn.1670219.

Byrka-Kita, K., Czerwiński, M., \& Preś-Perepeczo, A. (2017). Stock market reaction to CEO appointment-preliminary results. Journal of Management and Business Administration, 25(2), 23-42.

Cheung, W. J., \& Jackson, A. B. (2013). Chief Executive Officer departures and market uncertainty. Australian Journal of Management, 38(2), 279-310.

Clayton, M. C., Hartzell, J. C., \& Rosenberg, J. (2005). The impact of CEO turnover on equity volatility. The Journal of Business, 78(5), 1779-1808.

Dahya, J., McConnell, J. J., \& Travlos, N. G. (2002). The Cadbury committee, corporate performance, and top management turnover. The Journal of Finance, 57(1), 461-483.

Datta, D. K., \& Rajagopalan, N. (1998). Industry structure and CEO characteristics: An empirical study of succession events. Strategic Management Journal, 19(9), 833-852.

Dedman, E., \& Lin, S. W.-J. (2002). Shareholder wealth effects of CEO departures: Evidence from the UK. Journal of Corporate Finance, 8(1), 81-104.

Denis, D. J., \& Denis, D. K. (1995). Performance changes following top management dismissals. The Journal of Finance, $50(4), 1029-1057$

Dherment-Ferere, I., \& Renneboog, L. (2000). Share price reactions to CEO resignations and large shareholder monitoring in listed French companies. French: Tilburg University.

Friedman, S. D., \& Singh, H. (1989). CEO succession and stockholder reaction: The influence of organizational context and event content. Academy of Management Journal, 32(4), 718-744.

Furtado, E., \& Rozeff, M. (1987). The wealth effects of company initiated management changes. Journal of Financial Economics, $18(1), 147-160$.

Gamson, W., \& Scotch, N. (1964). Scapegoating in baseball. American Journal of Sociology, 70(1), 69-72.

Gangloff, K., Connelly, B., \& Shook, C. (2014). Of scapegoats and signals investor reactions to CEO succession in the aftermath of wrongdoing. Journal of Management and Business Administration, 42(6), 42-46.

Hartono, J. (2013). Portfolio theory and investment analysis (8th ed.). Yogyakarta:: BPFE.

Huson, M. R., Malatesta, P. H., \& Parrino, R. (2004). Managerial succession and firm performance. Journal of Financial Economics, 74(2), 237-275.

Ishak, R., Ismail, K., \& Abdullah, S. N. (2013). CEO succession and firm performance: Evidence from publicly listed Malaysian Firms. Asian Academy of Management Journal of Accounting and Finance, 9(2), 29-48.

Jenter, D., \& Lewellen, K. (2014). Performance-induced CEO turnover. Working Paper. Stanford, USA: Stanford University.

Kang, J.-K., \& Shivdasani, A. (1996). Does the Japanese governance system enhance shareholder wealth? Evidence from the stock-price effects of top management turnover. Review of Financial Studies, 9(4), 1061-1095.

Lindrianasari, \& Hartono, J. (2011). The relationship between accounting performance and CEO turnover: Evidence from Indonesia. Accounting \& Taxation, 3(2), 97-107.

Machdar, N. M. (2017). Corporate financial performance, corporate environmental performance, corporate social performance and stock return: An empirical study. Journal of Management and Entrepreneurship, 19(2), 118-124.

Mutwiri, K. (2013). The effect of chief executive officer' succession on the share price performance of listed firms in Kenya. University of Nairobi, Department of Finance and Accounting. Kenya: School of Business.

Neumann, R., \& Voetmann, T. (1999). CEO turnover and corporate governance: Evidence from copenhagen stock exchange. Paper presented at the Paper Presented at 26th. Annual Meeting of the European Finance Association at Vassa, Finland, 25-28 August 1999. 
Pessarossi, P., \& Weill, L. (2012). Does CEO turnover matter in China? Evidence from the stock market. BOFIT Discussion Papers 21. Findland: Bank of Finland, BOFIT Institute for Economies in Transition.

Rachpradit, P., Tang, J. C., \& Khang, D. B. (2012). CEO turnover and firm performance, evidence from Thailand. The International Journal of Business in Society, 12(2), 164-178.

Reinganum, M. (1985). The effect of executive succession on stockholder wealth. Administrative Science Quarterly, 30(1), 4660 .

Ross, S., Westereld, R., \& Jafe, J. (2013). Corporate finance. In Financial statements analysis and financial models (10th ed., pp. 53). New York: The McGraw-Hill Companies, Inc.

Salas, J. (2010). Entrenchment, governance, and the stock price reaction to sudden deaths. Journal of Banking छ Finance, 34(3), 656-666.

Setiawan, D. (2008). An analysis of market reaction to CEO turnover announcement: The case in Indonesia. International Business \& Economics Research Journal, 7(2), 119-127.

Setiawan, D., Phua, L. K., Chee, H. K., \& Trinugroho, I. (2017). CEO turnover and firm performance in Indonesia. Indonesian Capital Market Revierw, 9(1), 1-10.

Warner, J. B., Watts, R. L., \& Wruck, K. H. (1988). Stock prices and top management changes. Journal of Financial Economics, 20(1-2), 461-492.

Weisbach, M. (1988). Outside directors and CEO turnover. Journal of Financial Economics, 20(1-2), 43 1-460.

Zhang, P., Wierschem, D., Mediavilla, F. A., \& Hong, K. P. (2016). An empirical investigation on CEO turnover in IT firms and firm performance. Journal of International Technology and Information Management, 25(2), 67-82. 